Peer-Reviewed Article

ISSN: 2162-3104 Print/ ISSN: 2166-3750 Online Volume 7, Issue 4 (2017), pp. 1080-1095 (C) Journal of International Students http://jistudents.org/ doi: 10.5281/zenodo.1035969

\title{
A Collaborative Programming and Outreach Model for International Student Support Offices
}

\author{
Peter Briggs \\ Michigan State University, USA \\ Ravichandran Ammigan \\ University of Delaware, USA
}

\begin{abstract}
Increasing international student enrollment has been a key priority for many institutions of higher education in the United States. Such recruitment efforts, however, are often carried out without much consideration for providing sufficient support services to these students once they arrive to campus. This article proposes a model for structuring an international student support office to be successful at serving the academic, social and cultural needs of international students through a collaborative programming and outreach model with student affairs and other support service units on campus.
\end{abstract}

Keywords: international students, programming and outreach, student affairs, support services

The growth of international student enrollments at U.S. institutions over the past decade is shining a light on the complexity of what international students bring to a campus and what it takes to provide an appropriate level of support services to meet their needs. In spite of having long traditions of hosting students from around the world, this continued increase in numbers is calling for campuses to take a closer look at the challenges associated 1080 
with providing effective support services to this community. Institutions that have identified global engagement as one of their core strategic priorities are having to proactively develop and enhance their support model to meet the changing needs of their international student community and enrich the international student experience.

With the reach of institutions extending well beyond their local campuses into global communities, it has become essential for international education administrators to collaborate to a greater extent with student affairs and services personnel to not only serve more international students, but help all students develop global and intercultural competencies (American Council on Education, 2016). As universities and colleges continue to become increasingly interconnected through student mobility, exchange, experiential learning, and research, models of student affairs in the U.S. also have to expand and adapt to new cultural audiences and contexts. Residence life, housing, dining facilities, student organizations, and career and counseling services are not only regarded as universal elements of the collegiate experience but as a conscious effort to bring students together and contribute to define the educational mission of institutions as a global academic and social community (Ping, 1999). Working closely with student affairs professionals is therefore critical in moving the internationalization of higher education from vision to reality in the U.S. system of higher education.

It is important for institutions to recognize that retention relates to campus-wide experiences and that it is critical for multiple stakeholders to be involved in campus internationalization efforts that support the integration of international students into university life (Choudaha \& Schulmann, 2014). As trained educators and mentors of students, student affairs professionals have the necessary skills and technical knowhow to develop and coordinate programs that enhance inclusiveness, diversity, and culturally-rich learning environments on their campuses. One of the five recommendations that the NASPA Association's Research and Policy Institute offers to student affairs professionals is to establish campus wide partnerships that can support and contribute to the holistic learning, development and success of international students (Ting \& Morse, 2016).

For this to happen, however,

Student affairs leaders must nurture support for international programs and services, persuade others that international and domestic diversity is a necessity, and work closely with academic affairs leaders irrespective of the reporting lines of the international 
student office and study abroad office (Peterson, Briggs, Dreasher, Horner, \& Nelson, 1999, p. 67).

The contribution of student services staff is essential in serving the complex needs of international students and helping them develop global and intercultural competencies during their stay on campus and in the community (Ward, 2016).

International education can be a big industry when the resources generated are well known contributors to the institution's bottom line (de Wit, 2016). Inevitably, universities that have a strong focus on recruiting international students for revenue generation draw attention to whether they are doing enough to create a welcoming campus environment for these students and provide a platform for international programming and crosscultural engagement. It is not only traditional institutions that are seeing increased economic activity associated with the business of international students. The trend toward for-profit corporations taking on roles that were historically performed by colleges and universities has become a robust issue of strategy and ethics at all levels of higher education. In this context, it behooves all internationally minded institutions to begin by capitalizing on the strengths of their existing campus support services as they create strategic and collaborative student engagement programs that can, in turn, generate positive local stories and attitudes.

As we discuss this issue further, certain key questions arise: What is the appropriate level of service that support offices need to provide to international students so they can fully achieve their goals? How can an institution maximize educational benefits of the presence of this kind of global diversity on campus and in the community? This article presents a structured model of programming for international students that we hope will serve as a conversation starter on best practices for ensuring the success of this community. It advocates a vision that is clear, attainable, and realistic, and offers a collaborative model for contributing to the internationalization of the campus as well as the wider community.

\section{IMPORTANCE OF INTERNATIONAL STUDENT PROGRAMMING}

Over the years, institutions hosting international students have had to recalibrate their campus resources to address the substantial educational and cultural adjustment needed by these students to be successful (Bista, 2013). In the United States, international students are likely to experience more problems and take longer to adapt to local norms and customs than students 
who are originally from the United States (Kaczmarek, Matlock, Merta, Ames, \& Ross, 1984). These students are probably less exposed to available campus resources and may not know how to find support that can help them cope and adjust to their new home in the United States.

The recent introduction of immigration regulations, policies, and compliance standards by the U.S. government has undoubtedly created a high level of uncertainty and concern amongst international students studying in the United States. With a potential impact on overall international education exchanges and student mobility, institutions are having to reiterate their commitment, dedication and support towards international engagement and mutual understanding on their respective campuses (Choudaha, 2016). Offering programming and outreach support to international students during times of high stress can help them manage the many issues that they face, including language and cultural barriers associated with academic and social adjustment, as well as the emotional challenge often connected with the processes of acculturation. Through the implementation of culturally sensitive programming and interventions, effective outreach initiatives have proven to be successful by many in meeting the various needs of underserved and underrepresented university students (Nolan, Levy, \& Constantine, 1996). Such programs can also help strengthen the message that these students are welcomed on their respective campuses.

While many colleges and universities in the United States have specialized offices that assist international students on how to navigate complex immigration rules and regulations, not all offer dedicated services and programs that help with the acculturation and adjustment to the local campus community. Whether they are organized in the form of centralized or decentralized services, these resources, often offered in the form of cultural programming and engagement opportunities, are essential to the initial and ongoing success of international students and scholars during their stay in the United States (Wang, 2007).

According to Choudaha and $\mathrm{Hu}$ (2016), international students often interact with institutional silos. Despite the recognized needs and intent to serve international students, a vast majority of the institutions struggle and must do more to allocate adequate resources and expertise needed to work with this diverse population. Supporting, including, and engaging international students with the larger campus community can add tremendous value to the institution's overall campus internationalization efforts. It is therefore imperative for institutions looking to attract and retain 
international students to reinforce their services and programming initiatives so they meet the needs of these students and, in turn, cultivate an inclusive climate on their campuses (Ward, 2016).

\section{STRUCTURING THE ISSS OFFICE}

Before exploring the programming model, let us start by acknowledging the environment in which International Student Support Services (ISSS) offices exist on their respective campuses in the United States. Although the structure and organizational set up of these offices might differ from institution to institution, they all have one goal in common: to support international students in their academic, social and cultural transition during their studies (Pérez-Encinas \& Ammigan, 2016). However, all too often staff in these offices are forced to devote the majority of their time to administering U.S. government regulations and maintaining compliance with visa requirements. With limited time, funding, and staffing, this unique domain of expertise must remain the top priority or the campus might judge them harshly. As a starting point, the structure we suggest can serve as a basis for organizing an ISSS office to provide high-end regulatory as well as programming services.

An office can show its excellence and build reputation for competence with its unique area of expertise in advising on and interpreting government regulations. No other unit on campus handles this core responsibility and it is the ISSS office's duty to maintain high credibility with faculty, administration, and international students and scholars. Building inclusive relationships and collaborations across the campus and in the community can also be an important component for any ISSS office. The visibility gained in participating in planning committees and strategic task forces with key stakeholders such as Residence Life and Housing, Student Life, Career Services, Student Wellness, Academic Services, and Community Coalitions can build trust and relationships with the wider campus community even when the time spent is not directly related to international students. An ISSS office can then take an intentional approach at advancing campus internationalization through programming and outreach to explicit international points of contact. These key associations and entities can be educational, transformational, and important to the mission of helping bring global perspectives to students, staff, faculty, and community members. It can turn into a story of goodwill and hope that everyone can share and embrace. 


\section{DEVELOPING PROGRAMMING AND OUTREACH STRATEGIES}

Every innovative programming plan, design, or initiative rests on a few key assumptions. We offer six important ones below in the context of developing and implementing a successful international student programming and outreach model.

First, institutions must recognize that international students are a valuable educational and cultural resource that is too often underutilized and overlooked. International educators widely agree that bringing people of different cultural backgrounds into contact with each other can be educationally positive and life changing if done with the right structure (Wongtrirat, Ammigan, \& Pérez-Encinas, 2015). Building an inclusive community and a welcoming environment in which its members feel connected, safe, and engaged can be a powerful instrument that impacts students' sense of belonging, experience, and success. If intercultural programming is important to a campus' diversity goals, it becomes a missed opportunity not to make the international student community engaged as a more actively utilized resource. The University of Oregon's International Cultural Service Program (https://isss.uoregon.edu/icsp) is an excellent example of involving international students as educational resources in a highly intentional effort to bring international experiences to the campus and community. Program participants must complete an annual 80-hour "cultural service" requirement, by speaking in local school classes and community groups, in exchange for partial tuition assistance. ICSP is now in its 35 th year and has proven to be a highly successful model.

Second, it can be difficult for cross-cultural engagement to occur when international students are perceived to stay within their comfort zones and cultural groups (Stahl, 2012). This is an obstacle to students integrating and making contact across cultures, which can be so important to the educational mission of a campus. A study from Baruch College on international student friendship experiences in the United States found that more than one in three international students have no close American friends (Gareis, 2012). Moreover, the successful integration of international and domestic students is unlikely to occur just because the people are in the vicinity of each other. It is best achieved with staff whose mission it is to lead, plan, and facilitate this initiative. The American Council on Education's Leading Internationalization Report (2016) found that globally aware and culturally diverse staff who engage constructively with 
colleagues different from themselves and whose designated responsibilities are to seek out new global experiences can send a powerful signal to students that these qualities are valued in the campus community.

Third, during the period of time that international students are on campus, they are residing in, interacting with, and using resources from the local community. Opportunities for community engagement can lead to offcampus friendships, better integration with the American culture, business networking, create a positive impact on academic, social, and adjustment issues, and a more satisfying overall international student experience (Cormack, 1968; De Wit et al., 2008; Fleischman et al., 2010). NAFSA: Association of International Educators provides a dedicated set of resources on Campus and Community Programming (see http://www.nafsa.org/) suggesting that there is mutual benefit when community residents are more engaged with the global diversity amongst them. It is important to ensure that international students are taking advantage of experiential learning, career development, and internship opportunities available within their community and beyond during their stay in the United States.

Fourth, institutions should welcome opportunities to collaborate on initiatives to reach a wider audience and be intentional at engaging a variety of campus and community volunteers to be involved in these programs. Designing a cohesive, cross-departmental plan and coordinating more intentionally with student affairs offices and other service units on campus, can address the needs of students more effectively (Roy, Lu, \& Loo, 2016). With great access to international students as a programming resource, an ISSS office can also play a helpful role for student affairs and other offices around the university when they develop their own programs for campus internationalization.

Fifth, in addition to having adequate programs and resources in place for fostering an inclusive climate amongst students on campus, it is important for an institution to also build intercultural competence among its diverse stakeholders including the ISSS office, multicultural center, faculty, staff, and administrators (Choudaha, 2016). The ISSS office can play a key role in working closely with other student affairs professionals to lead this effort and provide the necessary intercultural training workshops and sessions that enhance communication skills and the ability to support, connect, and engage effectively with those who are different from us.

And sixth, an ISSS office must be intentional at developing a communication plan and establishing relevant assessment tools to effectively reach and gather feedback from their targeted audiences. Making 
sure that the ISSS website is user-friendly and accessible, standardizing mass-messaging protocols, promoting events via social media channels, using satisfaction and needs-based assessment surveys, and holding regular focus groups and student advisory committee meetings are good examples. In studying the social networking preferences of international students, Saw, Abbott, Donaghey, and McDonald (2013) found that students choose channels such as Twitter, YouTube, and Renren for a wide range of educational and social purposes, while Facebook remains the predominant choice. To ensure that international students receive critical and timely information on their immigration status and engagement opportunities, it is important for an ISSS office to be intentional at how messages are crafted and deployed to their targeted audiences.

\section{A PROGRAMMING AND OUTREACH MODEL}

The programming and outreach model illustrated in Figure 1 was initially developed by the authors in 2004 and has since been adopted by several institutions in the United States as a programming and outreach master plan for serving and engaging international students on their respective campuses. The model's success at Michigan State University (MSU) and the University of Delaware (UD) can take some credit for the institutions' strong rates of international student recruitment and retention (Institute of International Education, 2016). Its development grew out of the many years of experience the authors had in working with international students in higher education. With an increased emphasis on compliance with government regulations and declining resources, they saw the need to remain firm to longstanding core values of international education by bringing best practices to professional organizations in international education such as NAFSA (Association of International Educators), EAIE (European Association of International Educators) and ISANA (International Education Association).

The understanding of international student needs around the areas of academic success, social adjustment, and community engagement have been common standards to identify success for many years (Abe, Talbot, \& Geelhoed, 1998). Moreover, the nexus of international students and border security has been a periodic hot topic over the past forty years and the need for non-immigrant students to understand the issues around maintaining their legal immigration status became all the more important with the implementation of the U.S. Department of Homeland Security's electronic 
tracking system in 2003 (Rosser, Hermsen, Mamiseishvili, \& Wood, 2007). It is important to point out that learning objectives and outcomes should be clearly defined for each emphasis of programming at the time of program planning and development.

\section{Figure 1: A Collaborative Programming and Outreach Model}

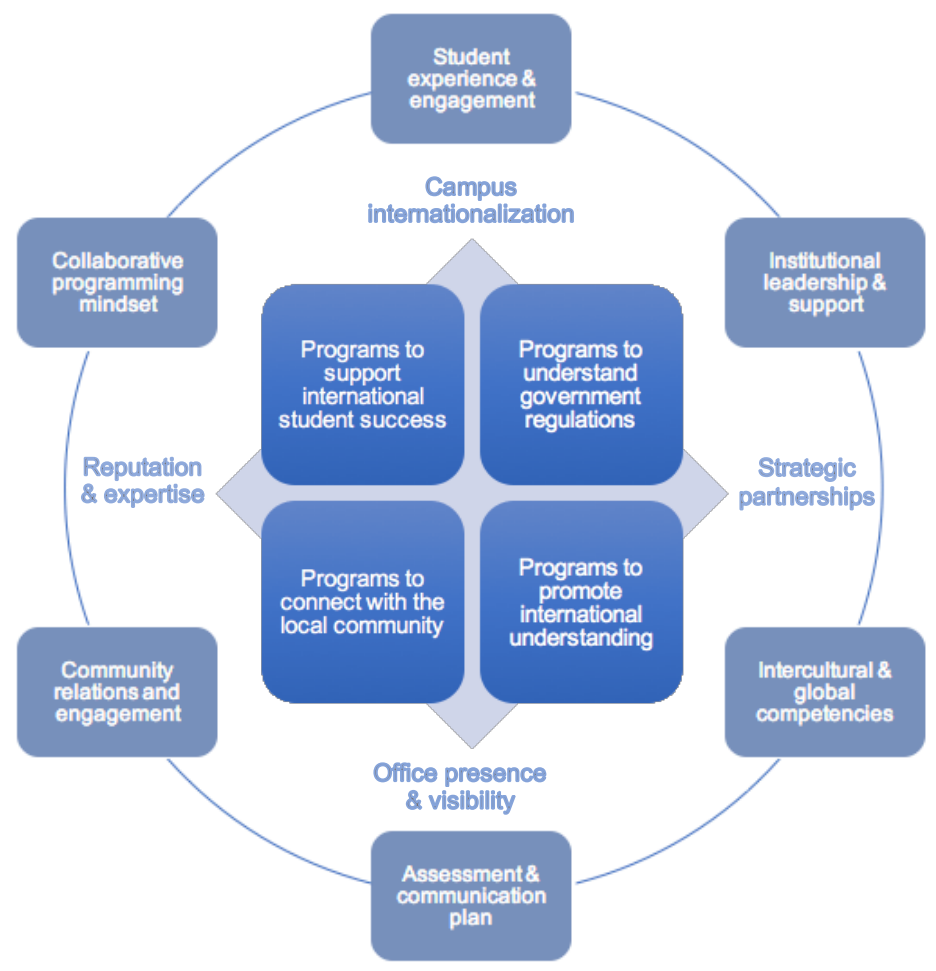

This model, which is further described with examples of programs and key stakeholders in the next section (see Table 1), is based on four pillars of service to international students:

\section{Programs to Support International Student Success}

The ISSS office should attend to the specific needs and well-being of international students and organize programs and workshops to help them be successful academically, socially, and culturally. This includes introducing new international students to the U.S. educational system that 
emphasizes analytical thinking and drawing conclusions. This contrast of learning expectations can feel like an abstract concept in an academic setting, thus the need for it to be covered more intentionally at new student orientation and first year learning programs. Examples include: U.S. classroom culture series, tutoring services, time management and study skills, academic honesty and plagiarism, tips for communicating with your teaching assistant, and language acquisition and support.

\section{Programs to Understand Government Regulations}

All international students are in the United States temporarily for the purpose of study and have special responsibilities that accompany their non-immigrant status. The ISSS office should conduct information sessions on government regulations pertaining to immigration, visas, and employment in the United States. Topics include: maintaining status in the United States, employment options for international students, travel advisories, and tax compliance issues.

\section{Programs to Promote International Understanding}

International students bring insights and perspectives that can contribute to cross-cultural sharing and learning. The ISSS office can help to provide opportunities on and off campus for this engagement to take place. This is one aspect of the internationalization of the university. Programs include: weekly coffee hour, essay contest, international education week, welcome reception, Life in the United States series, and making friends with Americans.

\section{Programs to Connect with the Local Community}

During the period of their studies at the university, international students are members of the local community. As the primary contact office for international students, the ISSS office can play a leadership role for organizing activities that make connections to members of the wider community. These activities include cultural excursions and field trips, visits to schools and community groups, networking with community leaders, holiday events and reception, and organizing friendship home visits.

\section{EXAMPLES OF SUCCESSFUL PROGRAMMING OUTCOMES}

In addition to a variety of examples listed in Table 1, we highlight a couple of programs that have been successful in establishing our programming 
model over the years at Michigan State University (MSU) and at the University of Delaware (UD).

\section{International Coffee Hour}

MSU's international coffee hour was originally launched in 2002 to provide a supportive structured gathering hub for international students and those who wished to be affiliated with the University's international community. Building on the new sense of international community, a group of students who became friends at the coffee hour enjoyed the spirit of community and recognized there was a need for a leading student organization to give voice to international student issues. This led to the formation of the International Students Association in 2003, which serves as the umbrella student organization for other nationality clubs and has grown to become one of the most influential student groups on campus.

Similarly at UD, the weekly coffee hour began as a way to build greater community and provide a space for informal interaction and crosscultural connection among diverse groups of international and domestic students and scholars. With over 200 in attendance each week, this program provides a platform for attendees to make friends, practice their language, learn about different cultures, and enjoy a free cup of coffee or tea in an organic fashion. Due to its popularity, the coffee hour has become an event open for official sponsorship opportunities, where campus and community partner offices share relevant resources and often provide free giveaways, snacks, music, and other cultural performances. It is also a place where student groups and other communities, such as international families and the International Student Advisory Committee, gather each week and provide feedback to the ISSS Office staff on issues pertaining to international students and scholars at the University.

\section{International Student Essay Contest}

MSU's international student essay contest was started in 2003 to counteract any concerns that international students might feel unwelcome with the implementation of new Homeland Security measures undertaken following the terrorist attacks in September 2001. It allowed international students to reflect on and tell their stories of living in a culture outside their own. The winning essay was printed each year in the local newspaper, the Lansing State Journal, thus giving the community an opportunity to build empathy for the challenges international students faced while living in Greater Lansing. Judges for the essay contest were picked from 
nontraditional sources that did not typically have daily interactions with international students, thus reaching out to new audiences and overcoming the old notion that international programming "preached to the already converted." The success of the essay contest that created a wider and positive image of international students, was embraced by another movement to retain talent in Michigan at a time when the state's economy was badly lagging. The Governor recognized that Michigan's universities were bringing talent in science, technology, education and math (STEM) disciplines that are drivers to economic development through innovation. The Governor's office subsequently formed the Global Talent Retention Initiative (GTRI) as one of several strategies for partnering with ISSS offices at universities within the State of Michigan.

At UD, the international student essay contest was launched in partnership with the Division of Student Life to foster international understanding and cross-cultural awareness on campus and in the community. This contest draws over 100 submissions each year, and like at MSU, all winning essays are made available for University and local Newark community members to read and "walk a mile in the shoes of an international student." Participating students are recognized at a reception during International Education Week and are invited to serve in an intercultural communication student panel discussion throughout the year as part of the institution's campus internationalization efforts.

\section{Career Services and Programs}

The ISSS offices at both MSU and UD have established successful partnerships with their Career Services to offer a set of programs and workshops designed to help international students in their job search strategies and networking with prospective employers in the United States. Navigating the legal and cultural landscape of American internships and jobs after graduation can be a challenging task for non-U.S. citizens. To support their career-preparation needs, joint workshops are offered every semester and include topics such as resume building, communication skills, immigration \& employment, and networking skills for international students. The series ends with a culminating session that provides an 


\section{Table 1: Examples of Key Programs and Stakeholders}

\begin{tabular}{|c|c|c|}
\hline & PROGRAMS & STAKEHOLDERS \\
\hline $\begin{array}{l}\text { 1. To support } \\
\text { student success }\end{array}$ & $\begin{array}{l}\text { U.S. classroom culture series; Using } \\
\text { campus tutoring services; Time } \\
\text { management and study skills; Academic } \\
\text { honesty and plagiarism; Working with } \\
\text { your TA; Language support programs; } \\
\text { Resume building; Mock job interviews; } \\
\text { Navigating the library; Relationships } \\
\text { and dating; Coping with culture shock; } \\
\text { Managing stress; Dealing with } \\
\text { expectations from home }\end{array}$ & $\begin{array}{l}\text { Office of Academic } \\
\text { Enrichment; TA Office; } \\
\text { Writing Center; Tutoring } \\
\text { Services; University Library; } \\
\text { Office of the Ombudsman; } \\
\text { English Language Program; } \\
\text { Career Services; Counseling } \\
\text { Center; Student Wellness; } \\
\text { Graduate Office; New Student } \\
\text { Orientation Office }\end{array}$ \\
\hline $\begin{array}{l}\text { 2. To understand } \\
\text { government } \\
\text { regulations }\end{array}$ & $\begin{array}{l}\text { Maintaining your legal visa status in the } \\
\text { U.S.; Post graduation employment } \\
\text { options; Finding an internship; Travel } \\
\text { advisories; Renewing your visa; Tax } \\
\text { compliance issues; Export Control; } \\
\text { Understanding healthcare and insurance; } \\
\text { Rights, responsibilities and personal } \\
\text { safety; Title IX workshops; Applying } \\
\text { for your Social Security Number; } \\
\text { Driving in the U.S. }\end{array}$ & $\begin{array}{l}\text { Office of General Counsel; } \\
\text { External immigration counsel; } \\
\text { Career Services; Research } \\
\text { Office; Student Health } \\
\text { Services; Law Clinic; Tax } \\
\text { Clinic Campus Police \& Safety; } \\
\text { Human Resources; Office of } \\
\text { Equity \& Inclusion; Social } \\
\text { Security Administration Office } \\
\text { and Dept. of Motor Vehicles }\end{array}$ \\
\hline $\begin{array}{l}\text { 3. To promote } \\
\text { international } \\
\text { understanding }\end{array}$ & $\begin{array}{l}\text { Weekly coffee hour; ice cream social; } \\
\text { essay contest; international education } \\
\text { week; welcome reception; Life in the } \\
\text { U.S. series; Making friends with } \\
\text { Americans; Residence Life mixer; } \\
\text { intercultural communication workshops; } \\
\text { film series; world cup tournament; } \\
\text { bowling nights; festival of nations; } \\
\text { Karaoke night }\end{array}$ & $\begin{array}{l}\text { Student Affairs, Residence Life } \\
\text { and Housing; President's and } \\
\text { Provost Office; Multicultural } \\
\text { Center; Recreational Services; } \\
\text { Athletics; Student Center; } \\
\text { Student and volunteer } \\
\text { Organizations; Athletics; } \\
\text { Various partner offices on } \\
\text { campus and in the community }\end{array}$ \\
\hline $\begin{array}{l}\text { 4. To connect with } \\
\text { the local } \\
\text { community }\end{array}$ & $\begin{array}{l}\text { Cultural excursions and field trips; visits } \\
\text { to schools and community groups; } \\
\text { networking with community leaders; } \\
\text { holiday events and reception; organizing } \\
\text { friendship home visits; tailgating party; } \\
\text { host family program; speakers bureau }\end{array}$ & $\begin{array}{l}\text { City Manager's Office; Local } \\
\text { schools, businesses and service } \\
\text { providers; Host families; Office } \\
\text { of Community Engagement and } \\
\text { Service Learning; Rotary Club; } \\
\text { Kiwanis Club }\end{array}$ \\
\hline
\end{tabular}

opportunity for students to meet fellow alumni working in the United States and put their new skills to work by mingling with prospective employers who have historically hired international students. At UD, this partnership has expanded to include staff training for university departments, online resources like job search portals for international students, and specialized outreach to future employers, where ISSS staff discuss the advantages of 
hiring international students as well as pathways to employment and visa options.

One key strategy that emerged from the formation of these programs is that good leadership can create a "myth" that becomes an inclusive idea with which people want to affiliate. The communication and branding tactic that the ISSS offices widely use for promoting the coffee hour and essay contest programs emphasizes that the university is an international welcoming campus and that the city is a globally friendly community. Reminding audiences, whenever possible, of the importance of community building and campus internationalization can directly impact their perception of and boost attendance at programs and events.

\section{CONCLUSION}

International students and scholars contribute greatly to all aspects of campus internationalization and present great opportunities for crosscultural learning and engagement. It is critical for the larger university community and administration to value their presence and recognize the important role they play in the life and sociocultural fabric of the institution. While many institutions are focused on increasing their international student enrollment due to financial pressures, they need to remain mindful of the importance of having a well-structured support system for when these students reach their campuses. Ensuring that their academic and social needs are met through a robust programming and outreach model, in collaboration with Student Affairs and other service units on campus, is key to providing them with a positive and successful experience during their stay on campus and in the United States.

\section{REFERENCES}

Abe, J., Talbot, D. M., \& Geelhoed, R. J. (1998). Effects of a peer program on international student adjustment. Journal of College Student Development, 39(6), 539-547.

American Council on Education. (2016). Leading internationalization: Student Affairs professionals make key contributions to campus internationalization. Retrieved from: http://www.acenet.edu/newsroom/Pages/Report-Highlights-Role-of-Student-Affairs-Professionals-inCampus-Internationalization.aspx

Bista, K. (2013, May 15). Internationalization in higher education: Needs and resources for international students. [Review of the books: International 
students: Strengthening a critical resource by M. S. Andrade \& N. W. Evans; International student security by S. Marginson, C. Nyland, E. Sawir, \& H. Forbes-Mewett; Understanding the international student experience by C. Montgomery], Global Studies Literature Review, 4, 1-2.

Choudaha, R. (2016). Campus readiness for supporting international student success. Journal of International Students, 6(4), I-V.

Choudaha, R. (2016, November 18). International educators build bridges, not walls. University World News. Retrieved from: http://www.universityworldnews.com

Choudaha, R. \& Hu, D. (2016, March 5). Higher education must go beyond recruitment and immigration compliance of international students. Forbes Education. Retrieved from: http://www.forbes.com

Choudaha, R. \& Schulmann, P. (2014). Bridging the gap: Recruitment and retention to improve international student experiences. Washington, DC: NAFSA.

Cormack, M. L. (1968). Chapter VII: International development through educational exchange. Review of Educational Research, 38(3), 293-302.

de Wit, H. (2016, April 6). Internationalization, more than revenue. Inside Higher $E d$. Retrieved from: https://www.insidehighered.com

Fleischman, D., Lawley, M., \& Raciti, M. M. (2010). Enhancing the international student experience with community engagement: A conceptual model. $e$ Journal of Business Education \& Scholarship of Teaching, 4(2), 13-26.

Gareis, E. (2012). Intercultural friendship: Effects of home and host region. Journal of International and Intercultural Communication, 5(4), 309-328.

Institute of International Education. (2016). Open doors report. Retrieved from: http://www.iie.org/Research-and-Publications/Open-Doors/Data

Kaczmarek, P. G., Matlock, G., Merta, R., Ames, M. H., \& Ross, M. (1994). An assessment of international college student adjustment. International Journal for the Advancement of Counseling, 17, 241-247.

Nilsson, J. E., Berkel, L. A., Flores, L. Y., \& Lucas, M. S. (2004). Utilization rate and presenting concerns of international students at a university counseling center: Implications for outreach programming. Journal of College Student Psychotherapy, 19(2), 49-59.

Nolan, J. M., Levy, E. G., \& Constantine, M. G. (1996). Meeting the developmental needs of diverse students: The impact of a peer education program. Journal of College Student Development, 37(5), 588-589.

Pérez-Encinas, A., \& Ammigan, R. (2016). Support services at Spanish and U.S. institutions: A driver for international student satisfaction. Journal of International Students, 6(4), 984-998.

Peterson, D. M., Briggs, P., Dreasher, L., Horner, D. D., \& Nelson, T. (1999). Contributions of international students and programs to campus diversity. New Directions for Student Services, 1999(86), 67-77.

Ping, C. J. (1999). An expanded international role for student affairs. New Directions for Student Services, 1999(86), 13-21. 
Rosser, V. J., Hermsen, J. M., Mamiseishvili, K., \& Wood, M. S. (2007). A national study examining the impact of SEVIS on international student and scholar advisors. Higher Education, 54(4), 525-542.

Roy, M., Lu, Z., \& Loo, B. (2016, October 4). The international student experience: A crucial domain of recruitment and retention. World Education Services. Retrieved from http://wenr.wes.org

Saw, G., Abbott, W., \& Donaghey, J., \& McDonald, C. (2013). Social media for international students-it's not all about Facebook. Library Management, 34(3), 156-174.

Stahl, J. (2012, June 19). Why aren't Americans and international students becoming friends? [Blog post] Retrieved from: https://blogs.voanews.com/student-union/2012/06/19/whyaren $\%$ E2\%80\%99t-americans-and-international-students-becoming-friends

Ting, R. S., \& Morse, A. (2016). 5 things student affairs professionals can do to support international students. Washington, DC: NASPA.

Wang, Y. (2007). International student' satisfaction with international student services and their college experience. Doctoral dissertation, Dowling College, Oakdale, NY.

Ward, H. (2016). Internationalization in action. Washington, DC: American Council on Education.

Wongtrirat, R., Ammigan, R., \& Pérez-Encinas, A. (2015). Building an inclusive community for international students. International Higher Education, 83, 17-18.

PETER BRIGGS, Director Emeritus at Michigan State University's Office for International Students and Scholars, retired in 2014 following a forty-year career as an international educator. He previously held administrative positions at the University of Oregon and the Institute of International Education. He served with NAFSA: Association of International Educators in a number of leadership positions, including Vice President for Regional Affairs and three terms on the Board of Directors. Email: pfb525@gmail.com

RAVICHANDRAN AMMIGAN is Executive Director of the Office for International Students and Scholars at the University of Delaware. He is pursuing a $\mathrm{PhD}$ in Higher Education Internationalisation at Università Cattolica del Sacro Cuore in Milan, Italy. His research examines international student satisfaction with campus living, learning, and general support services at institutions of higher education globally. Email: rammigan@udel.edu 